\title{
Effects of snails, submerged plants and their coexistence on eutrophication in aquatic ecosystems
}

\author{
Shuqing Mo ${ }^{1}$, Xiufeng Zhang ${ }^{1, *}$, Yali Tang ${ }^{1}$, Zhengwen Liu $^{1,2}$ and Nicholas Kettridge ${ }^{3}$ \\ ${ }^{1}$ Department of Ecology and Institute of Hydrobiology of Jinan University, Guangzhou 510632, PR China \\ 2 State Key Laboratory of Lake Science and Environment, Institute of Geography and Limnology, Chinese Academy of Sciences, \\ Nanjing 210008, PR China \\ ${ }^{3}$ School of Geography, Earth and Environment Sciences, Edgbaston, Birmingham B152TT, UK
}

\begin{abstract}
Eutrophication resulting from nutrient loading to freshwater habitats is a severe problem, leading to degradation of ecosystems, including deterioration of water quality, water clarity and loss of biodiversity. Measures enacted to restore degraded freshwater ecosystems often involve the reintroduction of submerged plants and aquatic animals with beneficial ecological functions. In a mesocosm experiment, three treatments (planting with Vallisneria natans, introduction of the snail Bellamya aeruginosa and a combined treatment with both plants and snails) were compared with controls to evaluate their effects on trophic state. The total nitrogen (TN), total phosphorus (TP) and chlorophyll $a(\mathrm{Chl} a)$ concentrations of planktonic and benthic algal samples were determined every two weeks, along with light intensity at the sediment surface. The plant-only treatment significantly reduced the TN levels and planktonic and benthic algal biomass and increased the light intensity at the sediment surface. The snail-only treatment reduced the concentrations of TN and reduced planktonic and benthic algal biomass. The combined treatment decreased the concentrations of TN and TP, reduced planktonic algal biomass and increased the light intensity on the sediment surface. The results indicate that while submerged plants and snails can both improve water quality, the most pronounced effect in aquatic ecosystems is achieved by their presence in combination. A combined reintroduction approach may provide enhanced benefits in restoring the eutrophic ecosystems, following the reduction of external nutrient loading.
\end{abstract}

Keywords: submerged plant / snail / coexistence / planktonic algae / benthic algae

Résumé - Effets des escargots, des plantes submergées et de leur coexistence sur l'eutrophisation dans les écosystèmes aquatiques. L'eutrophisation résultant de la charge nutritive dans les habitats d'eau douce est un problème grave, entraînant une dégradation des écosystèmes, y compris la détérioration de la qualité de l'eau, de la clarté de l'eau et la perte de biodiversité. Les mesures adoptées pour restaurer les écosystèmes d'eau douce dégradés impliquent souvent la réintroduction de plantes submergées et d'animaux aquatiques ayant des fonctions écologiques bénéfiques. Dans une expérience en mésocosme, trois traitements (plantation avec Vallisneria natans, introduction de l'escargot Bellamya aeruginosa et traitement combiné avec les plantes et les escargots) ont été comparés aux témoins pour évaluer leurs effets sur l'état trophique. Les concentrations d'azote total (TN), de phosphore total (TP) et de chlorophylle $a(\mathrm{Chl} a)$, des échantillons d'algues planctoniques et benthiques ont été déterminées toutes les deux semaines, ainsi que l'intensité de la lumière à la surface des sédiments. Le traitement aux plantes seules a réduit significativement les niveaux de $\mathrm{TN}$ et la biomasse d'algues planctoniques et benthiques et a augmenté l'intensité lumineuse à la surface des sédiments. Le traitement avec l'escargot seul a réduit les concentrations de TN et réduit la biomasse d'algues planctoniques et benthiques. Le traitement combiné a diminué les concentrations de TN et TP, réduit la biomasse d'algues planctoniques et augmenté l'intensité de la lumière sur la surface des sédiments. Les résultats indiquent que si les plantes submergées et les escargots peuvent améliorer la qualité de l'eau, l'effet le plus prononcé dans les écosystèmes aquatiques est obtenu par leur présence en combinaison. Une approche de réintroduction combinée peut apporter des

*Corresponding author: wetlandxfz@163.com 
avantages accrus dans la restauration des écosystèmes eutrophes, après réduction de la charge nutritive externe.

Mots clés : plante submergée / escargot / coexistence / algue planctonique / algue benthique

\section{Introduction}

Eutrophication due to nutrient loading is a serious problem in many freshwater ecosystems, leading to degradation of water quality, reduced clarity and loss of biodiversity. Scientists from various disciplines have taken a variety of approaches to tackling the problem and trialed a range of chemical, physical, biological and ecological methods designed to restore such degraded systems. However, many of these conventional methods have turned out in practice to be costly or environmentally unfriendly. The reintroduction of submerged plants and aquatic animals is often regarded as a more natural and practical means (Gao et al., 2017) of restoring degraded shallow water bodies.

Submerged plants are regarded as a powerful tool in freshwater habitat restoration (Li et al., 2008). Their contribution to improved water quality is affected through a series of biotic interactions and physico-chemical reactions with water and sediments (Ciurli et al., 2009). They limit the growth of planktonic algae through competition for nutrients (Carpenter and Lodge, 1986; Blindow et al., 1993; Nakai et al., 1996), alter the physico-chemical conditions of sediment (Qiu et al., 2001), reduce the resuspension of sediment materials, oxidize the water column, and actively absorb nutrients (Barko and James, 1998).

Freshwater snails are a common feature of the invertebrate fauna of aquatic ecosystems. The presence of snails has previously been shown to improve water clarity. By releasing substances that facilitate the coagulation of suspended particles (Wei and $\mathrm{Pu}, 1999$ ), snails may enhance the growth of submerged plants. Meanwhile, the grazing of snails has a direct impact on epiphytic communities (Marks and Lowe, 1989; Atalath et al., 2007), thereby resulting in an indirect effect on the growth of macrophytes (Bronmask, 1985). However, other researchers suggest that the actions of snails can contribute to sediment resuspension, enhance nutrient release to the water (Ciutat et al., 2007), and thereby exacerbate the problem of eutrophication. Thus the effects of snails on water quality have indicated both positive and negative effects.

Though many studies have examined the separate effects of either submerged plants or snails on water quality (Hilt et al., 2006; Soana and Bartoli, 2014), studies of interactions between these two important influences are limited. Li et al. (2009) suggested that living submerged plants would be eaten by snails such as Radix swinhoei, Lymnaea nurricula, Lymnaea stagnalis and the presence of species such as Parafossarulus striatulus and Bellamya aeruginosa were thought by Zhu et al. (2013) and Tan et al. (2015) to benefit macrophyte growth through their grazing on periphyton. However detailed investigations of the combined effect of snails and submerged macrophytes on the trophic status of aquatic ecosystems are lacking. In this study, 16 mesocosms were established to investigate the effects on eutrophication of submerged plants and snails acting both separately and in combination. Considering the benefits of snails on macrophyte and macrophyte's ability to clarify water, it was hypothesized that the addition of both of plants and snails to a system would yield greater water quality improvements than either measure alone. The results of this study will inform future efforts to restore degraded freshwater ecosystems.

The herbivorous snail B. aeruginosa was selected for use in the following experiment because it is a common and widely distributed feature of lakes or streams in China (Zhu et al., 2013). The clonal waterweed Vallisneria natans was selected because it is a highly adaptable species with a large geographical range, and already widely used in the restoration of eutrophic shallow lakes (Qiu et al., 2001). Specimens of $V$. natans grow perennially submersed and produce a basal rosette of leaves, which elongate up to the surface but do not form a canopy. The plant depends on light availability near the sediment for growth and survival. The root system is made up of adventitious roots without laterals (Xie et al., 2005; Bakker et al., 2010).

\section{Materials and methods}

\subsection{Experimental mesocosm set-up}

The mesocosm experiments were carried out in sixteen circular plastic barrels (upper diameter $\times$ bottom diameter $\times$ height $=50 \mathrm{~cm} \times 40 \mathrm{~cm} \times 60 \mathrm{~cm})$ containing rain water and a $10 \mathrm{~cm}$ deep layer of sediment. The sediment was collected from shallow Ming Lake in Guangzhou city, dried and sieved to remove coarse debris, and mixed to ensure uniformity. Rain water (total nitrogen $(\mathrm{TN})=1.19 \mathrm{mg} \cdot \mathrm{L}^{-1}$, total phosphorus $(\mathrm{TP})=0.01 \mathrm{mg} \cdot \mathrm{L}^{-1}$ ) was collected locally during the rainy season in April and May.

After the addition of water, the mesocosms were allowed to settle and maintained under natural sunlight for two weeks. Observed nutrient concentrations at the end of this acclimatization period were $\mathrm{TN}=1.01 \mathrm{mg} \cdot \mathrm{L}^{-1}, \mathrm{TP}=0.04 \mathrm{mg} \cdot \mathrm{L}^{-1}$ and the chlorophyll $a(\mathrm{Chl} a)$ concentration was $5.67 \mu \mathrm{g} \cdot \mathrm{L}^{-1}$. Nine evenly spaced $V$. natans were planted in each of eight mesocosms (Tab. 1); 50 B. aeruginosa were added to each of four planted mesocosms and the same number to each of four unplanted mesocosms. The remaining four mesocosms served as controls and received neither plants nor snails. Both $V$. natans and $B$. aeruginosa were originally sampled from Huizhou West Lake in Huizhou, Guangdong Province.

A petri dish (diameter $\times$ height $=3 \mathrm{~cm} \times 1 \mathrm{~cm})$ filled with sieved sediment was inserted into each mesocosm, so that the sediment surface inside the petri dish was exposed to the same light and nutrient regime, as well as grazing, as the sediment already present in the mesocosm, allowing benthic algae to colonize freely (Zhang et al., 2013).

Nitrogen as $\mathrm{KNO}_{3}\left(1.5 \mathrm{mgN} \cdot \mathrm{L}^{-1} \cdot\right.$ week $\left.^{-1}\right)$ and phosphorus as $\mathrm{NaH}_{2} \mathrm{PO}_{4}\left(0.1 \mathrm{mgP} \cdot \mathrm{L}^{-1} \cdot\right.$ week $\left.^{-1}\right)$ were added to each mesocosm every two weeks during the experiment. The experiment ran from April to August 2015 under natural sunlight conditions. 


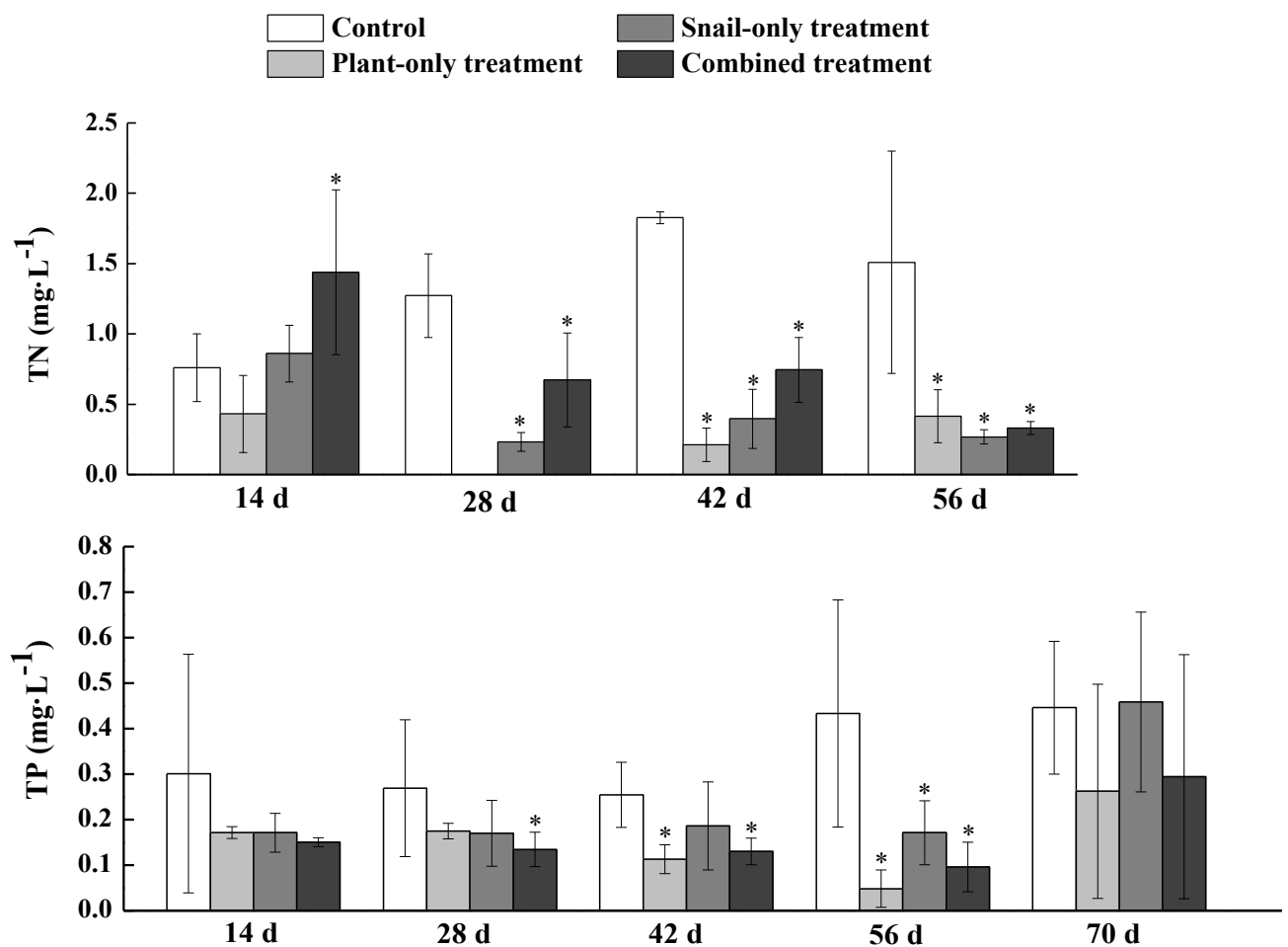

Fig. 1. TN and TP in different treatments. * indicates significant difference $(p<0.05)$ compared with controls. Vertical lines indicate $1 \mathrm{SD}$.

Table 1. Design of the mesocosm experiment.

\begin{tabular}{llc}
\hline Treatment & Description & Replicates \\
\hline Control & No plants, no snails & 4 \\
Plant-only & 9 V. natans $($ length $31 \pm 4.9 \mathrm{~cm}$ ), planted in each mesocosm & 4 \\
Snail-only & 50 B. aeruginosa $\left(\right.$ wet weight $0.98 \pm 0.22 \mathrm{~g} \cdot$ ind. $^{-1}$ ) added to each mesocosm & 4 \\
Combined plant + snail & $9 \mathrm{~V}$. natans and 50 B. aeruginosa added to each mesocosm & 4 \\
\hline
\end{tabular}

\subsection{Sampling and analysis}

Water samples $(1 \mathrm{~L})$ were collected from each mesocosm every two weeks during the experiment, for analysis of planktonic algal biomass ( $\mathrm{Chl} a)$, TN and TP. TP was analyzed using the ammonium molybdate-ascorbic acid method, after persulfate digestion (Clesceri et al., 1999). TN was digested with alkaline potassium persulfate and measured by absorbance (Li et al., 2008). Chl a was determined spectrophotometrically after ethanol extraction at room temperature, according to Jespersen and Christoffersen (1987).

Light intensity at the sediment surface was measured between 9:00 and 11:00 a.m. local time on each sampling day using an underwater irradiance meter (ZDS-10W).

The petri dishes with benthic algae were removed from the mesocosms after each sampling of water and replaced by fresh sediment-filled petri dishes. Benthic algae growing on the surface sediment of each dish were collected by scraping with a razor blade (Zhang et al., 2013). Chl a was measured spectrophotometrically, as for planktonic algae (Jespersen and Christoffersen, 1987).

\subsection{Statistical analyses}

Nutrient concentrations, Chl $a$ of planktonic and benthic algae, and light intensity were analyzed with repeated measures analyses of variance (RM-ANOVAs). Time effect was also analyzed with RM-ANOVAs. A least significant difference (LSD) test was used to detect different treatments when a significant difference was found. One-way ANOVA was performed to identify differences between treatments on each sampling occasion, and once again LSD tests were used to detect differing treatments. All statistical analyses were performed using SPSS 21.0 software. Data are presented as mean \pm 1 SD.

\section{Results}

\subsection{Nutrients}

TN concentrations were lower in the mesocosms with plants, snails or both than in the controls (RM-ANOVAs, treatment effect, $p<0.05)$. TP concentrations were also lower in both the plant-only and the combined treatments than in the controls (RM-ANOVAs, treatment effect, $p<0.05$ ). In addition, con- 


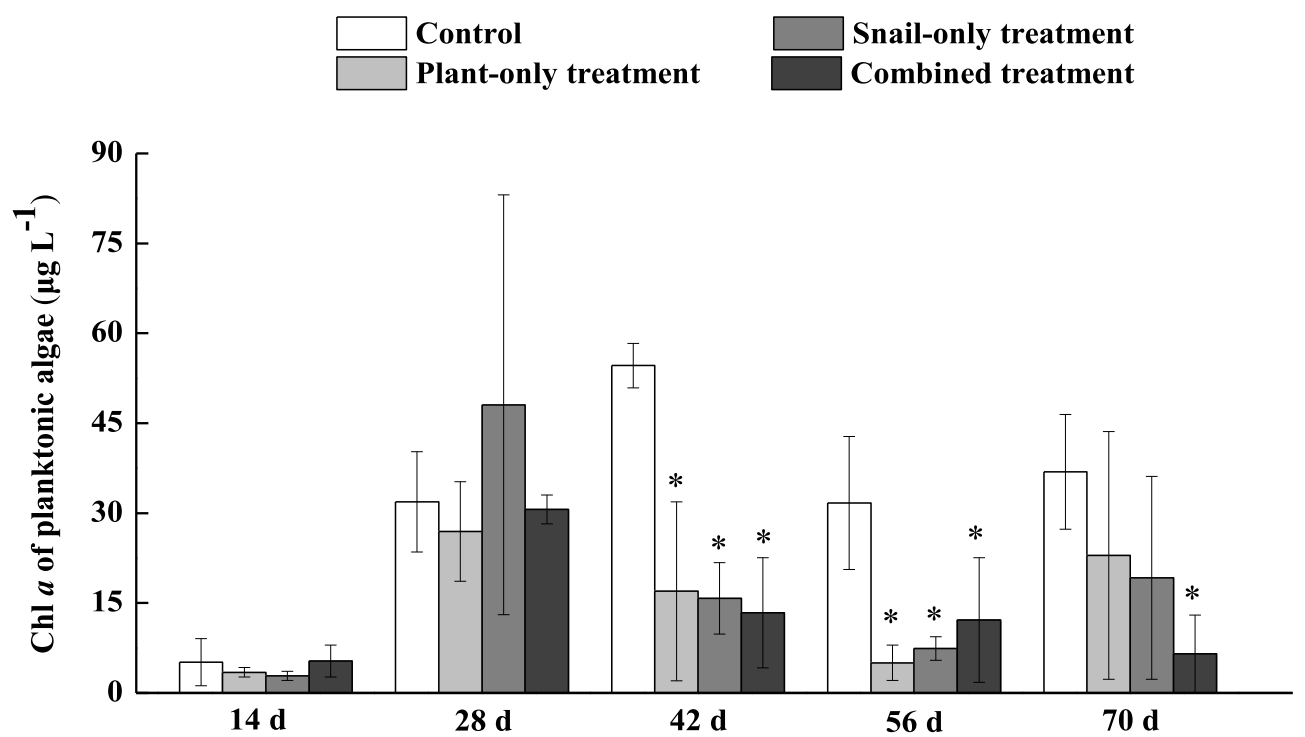

Fig. 2. Chl $a$ of planktonic algae in different treatments. * indicates significant difference $(p<0.05)$ compared with controls. Vertical lines indicate $1 \mathrm{SD}$.

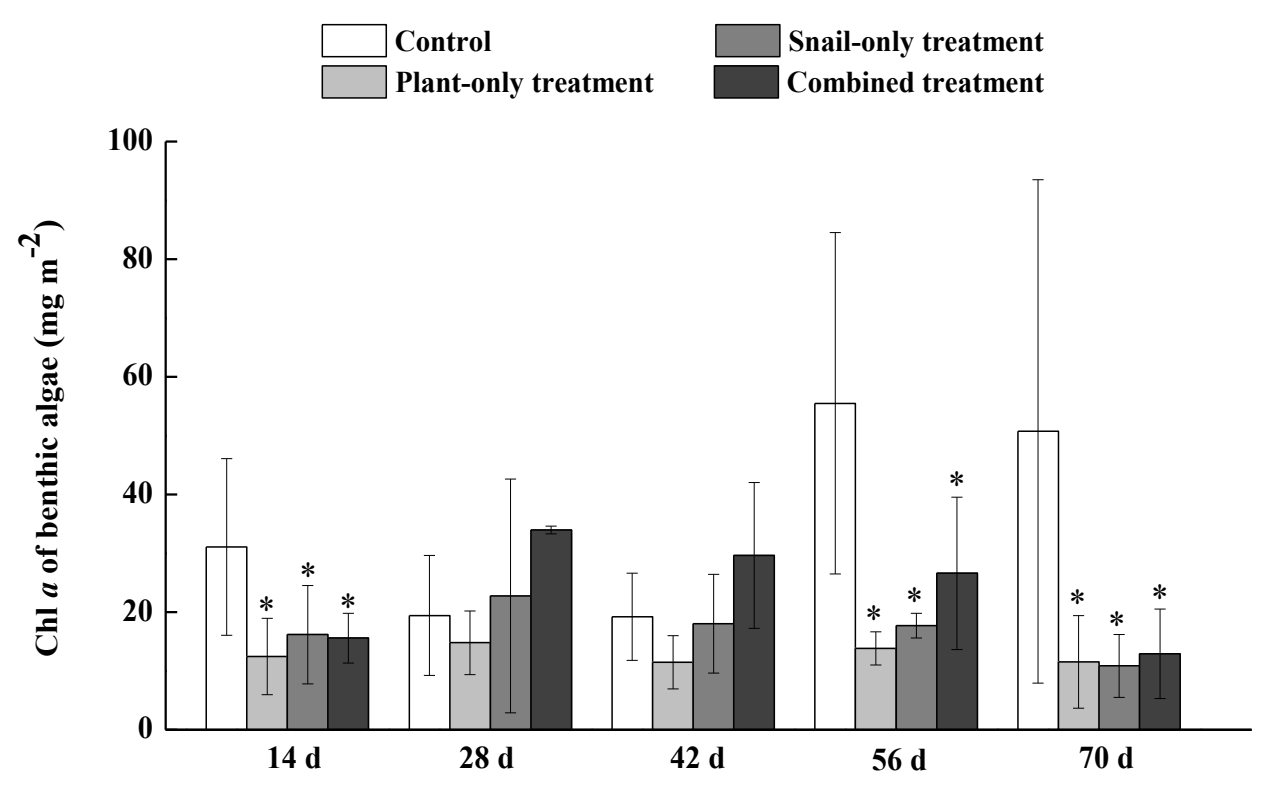

Fig. 3. Chl $a$ of benthic algae in different treatments. * indicates significant difference $(p<0.05)$ compared with controls. Vertical lines indicate $1 \mathrm{SD}$.

centrations of TN and TP in the plant-only treatments varied significantly over time (RM-ANOVAs, time effect, $p<0.05$ ).

TN concentrations were lower in the plant-only, snail-only and combined treatments than in the controls on every sampling occasion throughout the experiment, except at 14 days (one-way ANOVA, treatment effect, $p<0.05$; Fig. 1). Similarly, TP concentrations were lower in the plant-only treatments than in the controls at 42 and 56 days $(p<0.05$; Fig. 1$)$. TP concentrations were also lower in the snail-only treatments than in the controls at 56 days $(p<0.05)$, while TP concentrations were lower in the combined treatments than in the controls on every sampling occasion except at 14 and 70 days $(p<0.05)$.

\subsection{Planktonic algae}

Chl $a$ levels of planktonic algae were lower in the plantonly, snail-only and combined treatments than in the controls (RM-ANOVAs, treatment effect, $p<0.05$ ).

The Chl $a$ values of planktonic algae in all three treatments changed significantly with time (RM-ANOVAs, time effect, $p<0.05$ ). Chl $a$ levels were lower in the plant and snail treatments than in the controls at 42 and 56 days (one-way ANOVA, treatment effect, $p<0.05$; Fig. 2). On each sampling occasion, Chl $a$ levels were lower in the combined treatments 


\section{Control \\ Plant-only treatment

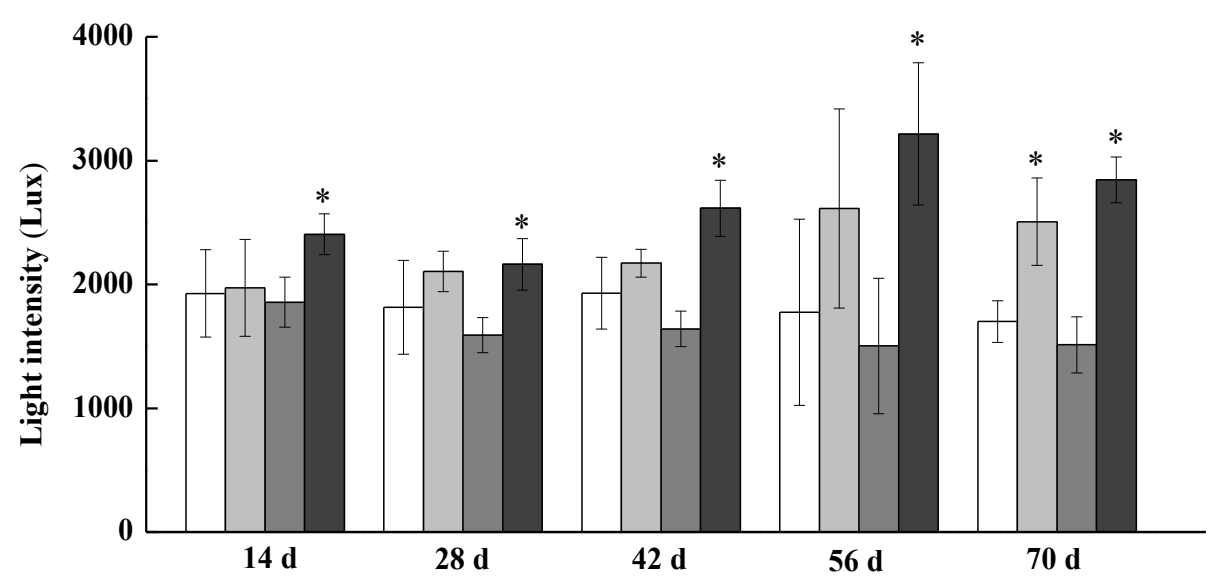

Fig. 4. Light intensity at the sediment surface in different treatments. ${ }^{*}$ indicates significant difference $(p<0.05)$ compared with controls. Vertical lines indicate 1 SD.

than in the controls throughout the experiment, except at 14 and 28 days $(p<0.05$; Fig. 2$)$.

\subsection{Benthic algae}

Chl $a$ levels of benthic algae were lower in the plant-only and snail-only treatments than in the controls (RM-ANOVAs, treatment effect, $p<0.05$ ).

The Chl $a$ values varied significantly with time (RMANOVAs, time effect, $p<0.05$ ), being lower in the plant-only, snail-only and combined treatments than in the controls at every sampling occasion throughout the experiment, except at 28 and 42 days (one-way ANOVA, treatment effect, $p<0.05$; Fig. 3).

\subsection{Light}

Light intensity at the sediment surface was higher in the plant-only and combined treatments than in the controls (RMANOVAs, treatment effect, $p<0.05$ ). In contrast, no significant difference of light intensity at the sediment surface was recorded in the snail treatments and the controls $(p>0.05)$. However, the light intensity was higher in the combined treatments than in the plant-only or snail-only treatments $(p<0.05)$. The Light intensity in the plant-only and combined treatments changed with time (RM-ANOVAs, time effect, $p<0.05$ ). Light intensity was higher in the plant-only treatments than in the controls at 70 days (one-way ANOVA, treatment effect, $p<0.05$; Fig. 4). Similarly, the light intensity was higher in the combined treatments than in the controls on every sampling occasion throughout the experiment $(p<0.05)$. However, there was no significant difference between the snail-only treatments and the controls on any sampling occasion $(p>0.05)$.

\section{Discussion}

Plants and snails both reduced TN concentrations and Chl $a$ levels in the water column, whether applied separately or in combination, while the plant-only and combined treatments also decreased TP levels. Plant-only and snail-only treatments appeared to suppressed the Chl $a$ levels at the sediment surface. In addition, plant-only and the combined plant + snail treatments increased the light intensity at the sediment surface, with the most pronounced effect on water clarity in the present study was achieved from a combined treatment.

Submerged plants have long been known to deplete nutrient levels in aquatic ecosystems (Reddy and Debusk, 1985). Xie et al. (2005) demonstrated that the roots of submerged macrophytes absorb nutrients from sediment while the leaves absorb the nutrients from water. Mulderij et al. (2005) showed that alleopathic substances secreted by the potentially invasive emergent Stratiotes aloides are able to decrease the growth of planktonic algae. Those findings are supported by the current results, showing that $V$. natans effectively reduces levels of $\mathrm{TN}$ and biomass of planktonic algae in the overlying water (Figs. 1 and 2).

While it has been suggested by Hillebrand et al. (2002) that snails can increase nutrients levels and stimulate planktonic algae growth with the products of their metabolism and by enhancing release of sediment nutrient, other authors report a negative influence on nutrients and planktonic algae levels. The mechanism proposed by Wei and $\mathrm{Pu}$ (1999) was flocculation, while Han et al. (2010) found that in rich planktonic algae conditions $B$. aeruginosa could adopt a filter feeding behaviour, and thereby make a notable impact on both biomass and nutrient levels. Our results also indicate a decline in TN levels (Fig. 1) and biomass of planktonic algae (Fig. 2) in the presence of snails.

There exists a mutual relationship between submerged plants and snails (Tan et al., 2015). Submerged plants may provide a good habitat for snails feeding on periphyton, and both the density and biomass of snails are larger where plants are abundant (Wang et al., 2006). When snails are absent, the growth of submerged plants is also adversely affected by overgrowth of periphyton (Hough et al., 1989; Pinowska, 2002). The presence of snails then increase the growth of submerged plants due to their grazing on organic detritus and periphyton. Thus, the coexistence of plants and snails may 
result in lower concentrations of nutrients and planktonic algae than either snails or submerged plants alone, and this could be a pertinent consideration in terms of water quality improvement.

Water clarity is an important index of water quality, and is also affected by submerged plants and aquatic animals (Vadeboncoeur et al., 2003; Zhang et al., 2015). The current study shows that $V$. natans plays a significant role in improving water clarity as measured by the light intensity at the sediment surface in both plant-only and combined treatments. In contrast, light intensity at the sediment surface was lower in the snail-only treatments, suggesting that the presence of snails adversely affect clarity (Fig. 4), most likely as a result of bioturbation as the snails crawl and feed, and also through the release of snail metabolites (Reise, 1985).

In shallow lakes, light is always a limiting factor affecting the growth of benthic algae (Hansson, 1988), and improved light conditions are generally expected to stimulate algal growth (Zhang et al., 2013, 2014). However, in the present study the biomass of benthic algae decreased in plant-only and snail-only treatments compared to the control. The decreased biomass of benthic algae in the plant-only treatments is likely attributed to reduced nutrient availability and possible allelopathic effects of the submerged plants. Meanwhile, the decreased benthic algae biomass in the snail-only treatments may also be enhanced by low light intensity (Hansson, 1988) and/or grazing (Feminella and Hawkins, 1995; Hillebrand, 2002). Reduced biomass of benthic algae due to grazing by snails has previously been demonstrated by Tuchman and Stevenson (1991).

The density of snails varies naturally in different lakes. For instance, the average density of $B$. aeruginosa in China's Lake Taihu is 102 ind. $\mathrm{m}^{-2}$ (Cai et al., 2009), but there is considerable variation in different areas, and values up to 299 ind. $\mathrm{m}^{-2}$ were recorded in East Bay, a part of the lake dominated by submerged plants (Cai et al., 2009). Gong et al. (2009) reported the density of B. aeruginosa in Lake Donghu as 157 ind. $\cdot \mathrm{m}^{-2}$, while earlier studies found densities of over 500 ind. $\cdot \mathrm{m}^{-2}$. The effective density of snails in our study is $\approx 398 \mathrm{ind} \cdot \mathrm{m}^{-2}$, close to the $400 \mathrm{ind} \cdot \mathrm{m}^{-2}$ reported by Zhu et al. (2013) in their enclosure experiment using the same species.

In conclusion, while both submerged plants and snails can improve water quality in aquatic systems, the most pronounced effect is likely to be achieved through a combined treatment, and such an approach may be useful in restoring eutrophic ecosystems.

Acknowledgments. The authors are grateful to Zhongkui $\mathrm{Wu}$ for his assistance in sampling and sample analyses. This study was sponsored by the National Natural Science Foundation of China (Nos. 31570456 and 41771100) and Provincial Natural Science Foundation of Guangdong (No. 2016A030313103).

\section{References}

Atalath J, Anderson MJ, Costello MJ. 2007. Temporal variability and intensity of grazing: a mesocosm experiment. Mar Ecol Prog Ser 341: 15-24.

Bakker ES, Van Donk E, Declerck SAJ, et al. 2010. Effects of macrophyte community composition and nutrient enrichment on plant biomass and algal blooms. Basic Appl Ecol 11: 432-439.
Barko JW, James WF. 1998. Effects of submerged aquatic macrophytes on nutrient dynamics, sedimentation, and resuspension. In: Jeppesen E, Søndergaard M, Søndergaard M, Christoffersen K, eds. The structuring role of submerged macrophytes in lakes. Ecological studies. New York: Springer, pp. 197-214.

Blindow I, Andersson G, Hargeby A, Johansson S. 1993. Long-term pattern of alternative stable states in two shallow eutrophic lakes. Freshw Biol 30: 159-167.

Bronmask C. 1985. Interactions between macrophytes, epiphytes and herbivores: an experimental approach. Oikos 45: 26-30.

Cai Y, Gong Z, Qin B. 2009. Standing crop and spatial distributional pattern of Mollusca in Lake Taihu, 2006-2007. J Lake Sci 21: 713-719 (in Chinese with an English abstract).

Carpenter SR, Lodge DM. 1986. Effects of submersed macrophytes on ecosystem processes. Aquat Bot 26: 341-370.

Ciurli A, Zuccarini P, Alpi A. 2009. Growth and nutrient absorption of two submerged aquatic macrophytes in mesocosms, for reinsertion in a eutrophicated shallow lake. Wetl Ecol Manag 17: 107-115.

Ciutat A, Gerino M, Boudou A. 2007. Remobilization and bioavailability of cadmium from historically contaminated sediment: influence of bioturbation by tubificids. Ecotoxicol Environ Safe 68: 108-117.

Clesceri LS, Greenberg AE, Trussel RR. 1999. Standard methods for the examination of water and wastewater, 17th ed. Washington, DC: American Public Health Association.

Feminella JW, Hawkins CP. 1995. Interactions between stream herbivores and periphyton: a quantitative analysis of past experiments. J N Am Benthol Soc 14: 465-509.

Gao H, Qian X, Wu H, et al. 2017. Combined effects of submerged macrophytes and aquatic animals on the restoration of a eutrophic water body - a case study of Gonghu Bay, Lake Taihu. Ecol Eng 102: $15-23$

Gong Z, Li Y, Xie P. 2009. Population dynamics and production of Bellamya aeruginosa (Reeve) (Mollusca: Viviparidae) in Lake Donghu, Wuhan. J Lake Sci 21: 401-407 (in Chinese with an English abstract).

Han S, Yan S, Chen K, et al. 2010. ${ }^{15} \mathrm{~N}$ isotope fractionation in an aquatic food chain: Bellamya aeruginosa (Reeve) as an algal control agent. J Environ Sci 22: 242-247.

Hansson LA. 1988. Effects of competitive interactions on the biomass development of planktonic and periphytic algae in lakes. Limnol Oceanogr 33: 121-128.

Hillebrand H. 2002. Top-down versus bottom-up control of autotrophic biomass - a meta-analysis on experiments with periphyton. J N Am Benthol Soc 21: 349-369.

Hillebrand H, Kahlert M, Haglund AL, et al. 2002. Control of microbenthic communities by grazing and nutrient supply. Ecology 83: 2205-2219.

Hilt S, Gross EM, Hupfer M. 2006. Restoration of submerged vegetation in shallow eutrophic lakes - a guideline and state of the art in Germany. Limnologica 36: 155-171.

Hough RA, Fornwall MD, Negele BJ, et al. 1989. Plant community dynamics in a chain of lakes: principal factors in the decline of rooted macrophytes with eutrophication. Hydrobiologia 173: 199-217.

Jespersen AM, Christoffersen K. 1987. Measurements of chlorophyll$a$ from phytoplankton using ethanol as extraction solvent. Arch Hydrobiol 109: 445-454.

Li K, Liu Z, Binhe G. 2008. Persistence of clear water in a nutrientimpacted region of Lake Taihu: the role of periphyton grazing by snails. Fund Appl Limnol 173: 15-20.

Li K, Liu Z, Hu Y, Yang H. 2009. Snail herbivory on submerged macrophytes and nutrient release: implications for macrophyte management. Ecol Eng 35: 1664-1667. 
Marks JC, Lowe RL. 1989. The independent and interactive effects of snail grazing and nutrient enrichment on structuring periphyton communities. Hydrobiologia 185: 9-17.

Mulderij G, Mooil WM, Smolders AJP, Van Donk E. 2005. Allelopathic inhibition of phytoplankton by exudates from Stratiotes aloides. Aquat Bot 82: 284-296.

Nakai S, Hosomi M, Okada M, Murakami A. 1996. Control of algal growth by macrophytes and macrophyte-extracted bioactive compounds. Water Sci Technol 34: 227-235.

Nozaki K, Darijav K, Akatsuka T, et al. 2003. Development of filamentous green algae in the benthic algal community in a littoral sand-beach zone of Lake Biwa. Limnology 4: 161-165.

Pinowska A. 2002. Effects of snail grazing and nutrient release on growth of the macrophytes Ceratophyllum demersum and Elodea canadensis and the filamentous green alga Cladophora sp. Hydrobiologia 479: 83-94.

Qiu D, Wu Z, Liu B, et al. 2001. The restoration of aquatic macrophytes for improving water quality in hypertrophic shallow lake in Hubei Province, China. Ecol Eng 18: 147-156.

Reddy KR, Debusk TA. 1985. Nutrient removal potential of selected aquatic macrophytes. J Environ Qual 14: 459-462.

Reise K. 1985. Tidal flat ecology: an experimental approach to species interactions. New York: Springer-Verlag.

Soana E, Bartoli M. 2014. Seasonal regulation of nitrification in a rooted macrophyte (Vallisneria spiralis) meadow under eutrophic conditions. Aquat Ecol 48: 11-21.

Tan B, Zhu X, Ning X, et al. 2015. Effects of Parafossarulus striatulus on the growth of Vasllisneria spiralis. Acta Ecol Sin 35: 3199-3203 (in Chinese with an English abstract).
Tuchman NC, Stevenson RJ. 1991. Effects of selective grazing by snails on benthic algal succession. J N Am Benthol Soc 10: 430-443.

Vadeboncoeur Y, Jeppesen E, Vander Zanden MJ, et al. 2003. From Greenland to green lakes: cultural eutrophication and the loss of benthic pathways in lakes. Limnol Oceanog 48: 1408-1418.

Wang H, Pan B, Liang X, Wang H. 2006. Gastropods on submersed macrophytes in Yangtze Lakes: community characteristics and empirical modeling. Int Rev Hydrobiol 91: 521-538.

Wei Y, Pu P. 1999. Abatement of the nitrogen and phosphorus concentration in water by the snail Bellamya aeruginosa in Lake Taihu. Resour Environ Yangtze Basin 8: 89-93 (in Chinese with an English abstract).

Xie Y, An S, Yao X, et al. 2005. Short time response in root morphology of Vallisneria natans to sediment type and watercolumn nutrient. Aquat Bot 81: 85-96.

Zhang X, Liu Z, Gulati RD, Jeppesen E. 2013. The effect of benthic algae on phosphorus exchange between sediment and overlying water in shallow lake: a microcosm study using ${ }^{32} \mathrm{P}$ as tracer. Hydrobiologia 710: 109-116.

Zhang X, Liu Z, Jeppesen E, Taylor WD. 2014. Effects of depositfeeding tubificid worms and filter-feeding bivalves on benthicpelagic coupling: Implications for the restoration of eutrophic shallow lakes. Water Res 50: 135-146.

Zhang X, Mei X, Gulati RD, Liu Z. 2015. Effects of N and P enrichments on the competition between phytoplankton and benthic algae in shallow lakes: based on a mesocosm study. Environ Sci Pollut Res 22: 4418-4424.

Zhu J, Lu K, Liu X. 2013. Can the freshwater snail Bellamya aeruginosa (Mollusca) affect phytoplankton community and water quality? Hydrobiologia 707: 147-157.

Cite this article as: Mo S, Zhang X, Tang Y, Liu Z, Kettridge N. 2017. Effects of snails, submerged plants and their coexistence on eutrophication in aquatic ecosystems. Knowl. Manag. Aquat. Ecosyst., 418, 44. 